\title{
Environmental characteristics and changes of bacterial communities in the meltwater runoff of glacier in Ny-Alesund, Arctic
}

\section{Lidong Lin}

Qingdao University

Nengfei Wang ( $\nabla$ wangnengfei@fio.org.cn )

Qingdao University

\section{Wenbing Han}

First Institute of Oceanography, Ministry of Natural Resources

\section{Botao Zhang}

Qingdao University

\section{Jiaye Zang}

First Institute of Oceanography, Ministry of Natural Resources

\section{Qinxin Li}

Qingdao University

\section{Yiling Qin}

First Institute of Oceanography, Ministry of Natural Resources

\section{Long Wang}

Qingdao University of Science \& Technology

\section{Fang Zhang}

Polar Research Institute of China

Jie Liu

Qingdao University of Science \& Technology

\section{Research Article}

Keywords: Arctic, High-throughput sequencing, Glacier meltwater, Bacterial diversity, Geochemical property

Posted Date: September 20th, 2021

DOI: https://doi.org/10.21203/rs.3.rs-906889/v1

License: (c) (1) This work is licensed under a Creative Commons Attribution 4.0 International License. 

Environmental characteristics and changes of bacterial communities in the meltwater runoff of glacier in Ny-Alesund, Arctic

Lidong $\operatorname{Lin}^{\dagger} \cdot$ Nengfei Wang ${ }^{\dagger} *$ Wenbing Han $\cdot$ Botao Zhang $\cdot$ Jiaye Zang · Qinxin Li · Yiling Qin •

Long Wang · Fang Zhang · Jie Liu

*Correspondence: N. Wang

†These authors have contributed equally to this work

L. Lin · B. Zhang $\cdot$ Q. Li

College of Chemistry and Chemical Engineering, Qingdao University, Qingdao 266071, China

N. Wang*. W. Han · J. Zang · Y. Qin

First Institute of Oceanography, Ministry of Natural Resources, Qingdao 266061, China

e-mail: wangnengfei@fio.org.cn

L. Wang · J. Liu

Department of Bioengineering, College of Marine Sciences and Biological Engineering, Qingdao University of Science \& Technology, Qingdao 266042, China

F. Zhang

Polar Research Institute of China, Shanghai 200136, China

\section{Abstract}

The present study assessed the diversity and composition of bacterial communities in glacial runoff and glacial soils in the Midre Lovénbreen glacier region of Svalbard. A total of 6,593 operational taxonomic units were identified by high-throughput sequencing. The results showed differences in bacterial community composition between the upper and lower reaches of glacial runoff. The abundance of Actinobacteria, Firmicutes, Betaproteobacteria and Gammaproteobacteria in the upper reaches of glacial runoff was higher than that in the lower reaches. In contrast, the the abundance of Cyanobacteria and Alphaproteobacteria in the downstream of glacial runoff was higher than that in the upstream. In addition, we compared bacterial diversity and composition between glacial runoff areas and soils. The chart analysis showed that bacterial diversity in glacial soil was higher than that in the glacial runoff. Some typical bacteria in the soil, such as Actinobacteria, entered glacial runoff through contact between them. The abundance of Acidobacteria, Sphingobacterium and Flavobacterium was higher in glacial soil. Weighted correlation network analysis showed that the core bacteria in glacial runoff and glacial soil were typical bacteria in different habitats. Distance-based redundancy analysis revealed that $\mathrm{NO}_{2}-\mathrm{N}$ was the most significant factor affecting the distribution of soil bacterial community, while $\mathrm{NO}_{3}{ }^{-}-\mathrm{N}$ was the most significant factor affecting the distribution of glacial runoff bacterial community.

\section{Keywords}

Arctic $\cdot$ High-throughput sequencing $\cdot$ Glacier meltwater $\cdot$ Bacterial diversity $\cdot$ Geochemical property 



\section{Introduction}

Svalbard's glaciers and ice sheets account for about $6 \%$ of the world's glaciers outside the Greenland and Antarctic ice sheets (Farinotti et al. 2019). The Arctic has warmed twice as much as the global average over the past 20 years due to global warming, and is on the edge of Arctic sea ice retreat, making the Svalbard glacier one of the fastest-warming regions on Earth (Noël et al. 2020). As glaciers recede, new landscapes are exposed, providing opportunities for various life forms to colonize and inherit processes in time and space (Pendleton et al. 2019). In the last few decades, researchers have come up with the concept of glacial ecology (Hodson et al. 2008). Bacteria were the dominant microorganisms in the glacial niche, followed by fungi and algae (Anesio et al. 2017). However, the biological resources with high biotechnological potential under the glacial niche have not been fully exploited. Therefore, more and more attention has been paid to evaluating biological resources and biological processes in glacial ecosystems. Microbial diversity, ecological and biogeochemical processes, and microbial impacts on climate change in the Arctic have been extensively explored in the areas of the glacial foreland, glacial runoff, and glaciers meltwater into lakes (Venkatachalam et al. 2021; N. Wang et al. 2019; N. F. Wang et al. 2016; T. Zhang et al. 2016). So far, however, there are few studies on the differences in microbial diversity between the upper and lower reaches of glacial runoff and between glacial runoff and glacial soil. In addition, the differences of core flora between glacial runoff and glacial soil have been rarely reported.

Glaciers at different geographical locations show significant differences in microbial community structure (Liu et al. 2009; X. Zhang et al. 2009), controlled by several environmental and climatic drivers (Bhatia et al. 2006; Takeuchi Kohshima 2004). Therefore, it can be said that microorganisms are sensitive indicators of climate change and a component of biogeochemistry (Guo et al. 2018; N. F. Wang et al. 2015). In addition, subglacial microorganisms play an essential role in driving biogeochemical cycles of carbon, nitrogen and phosphorus in the High Arctic (N. F. Wang et al. 2016). In glacial habitats, when temperatures are high, upstream glacial runoff first interacts with glacial soils and then flows into lakes or streams (Yang et al. 2016). The soil is connected to lakes and streams, it is an essential microbial niche in glacial ecosystems, regulating biogeochemical cycles. As glacier retreat continues, glacial runoff flows downstream into estuaries, thereby diverting nutrients and microbial communities from glacial meltwater into the ocean (Sajjad et al. 2020).

Studies have shown that different habitats in the same glacier inhabit different microbial communities, and there are few common taxa (Sajjad et al. 2021). Previous studies have reported significant differences in bacterial diversity between glacial soils and snow cover, as well as changes in microbial community diversity and composition in alpine glaciers caused by glacier retreat (Wilhelm et al. 2013; Yang et al. 2016). However, there is insufficient information on the overall variation of glacial runoff bacterial communities from upstream to the estuary and the interaction between glacial runoff and soil. Therefore, we used high-throughput sequencing to evaluate the glacial runoff and adjacent soils of the Midre Lovénbreen glacier in Svalbard, as well as the seawater at the downstream estuary. This study mainly solves the following problems: (1) the difference of bacterial taxa from upstream to downstream in glacial runoff from Midre Lovénbreen glacier; (2) the relationship between glacial runoff and bacterial community composition in glacial soil; (3) what are the key geochemical factors that determine the runoff of the Midre Lovénbreen glacier and the composition of the bacterial community of the glacial soil? 


\section{Materials and Methods}

\section{Study Sites and Sample Collection}

Midre Lovénbreen glacier is located in the Kongsfjorden region of Svalbard $\left(78^{\circ} 53^{\prime} 703^{\prime \prime} \mathrm{N}\right.$ $12^{\circ} 02^{\prime} 475^{\prime \prime} \mathrm{E}$ ), in the Arctic. The glacier is about $6 \mathrm{~km}$ long, covers an area of about $5.5 \mathrm{~km}^{2}$ and has a maximum thickness of about $180 \mathrm{~m}$ (Björnsson et al. 1996). The altitude of the glacier at the snout is about $50 \mathrm{~m}$ and increases to about $600 \mathrm{~m}$ above sea level at the head wall (Reddy et al. 2009). The distance from the mouth of the glacier to the point where meltwater flows into the ocean is about 2-3 $\mathrm{km}$.

Sampling sites are shown in the figure (Fig. 1), we set up 12 sampling sites along the glacier runoff from upstream to downstream. Among them, 8 sampling points collected water samples from glacial runoff (SR01-SR08), and 3 sampling points collected soil samples from glacial soil (M2-M4). Water samples were directly collected into TWIRL'EM sterile sampling bags (Labplas Inc., Canada). The microbial samples were then collected by filtering $1000 \mathrm{ml}$ of the water samples. The microbial biomass was successively trapped onto 47-mm-diameter, 0.2- $\mu$ mpore-size membrane filters (Pall Corporation, USA). Membrane filters were placed in centrifuge tubes at $-20{ }^{\circ} \mathrm{C}$ in the Yellow River Station (China) and taken to the laboratory by plane. Filters were then frozen at $-80{ }^{\circ} \mathrm{C}$ until nucleic acid extraction. Surface soils sample $(0-5 \mathrm{~cm})$ were collected in triplicate (approximately $1 \mathrm{~m}$ from each other) and placed into TWIRL'EM sterile sampling bags (Labplas, Sainte-Julie, QC, Canada). Samples were stored at $-80^{\circ} \mathrm{C}$ at China's Arctic Yellow River Station before being transported on ice by air to the home laboratory, at which they were stored at $-80^{\circ} \mathrm{C}$ until DNA extraction.
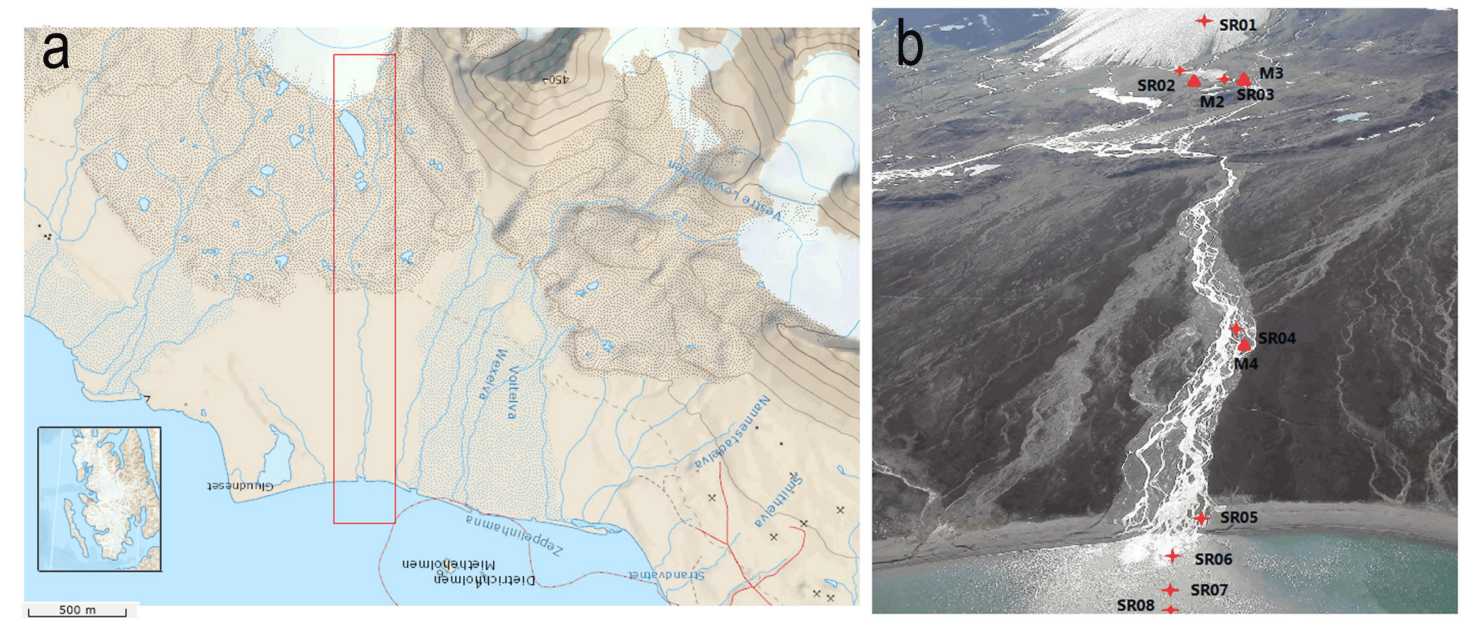

Fig.1 Location (red dot; a) and image (b) of the sampling sites from Midre Lovénbreen glacier area in the present study.

Geochemical properties of the sample

A total of 8 soil properties were measured, including $\mathrm{MC}, \mathrm{pH}$, organic carbon (C), organic nitrogen $(\mathrm{N})$, ammonium nitrogen $\left(\mathrm{NH}_{4}{ }^{+}-\mathrm{N}\right)$, silicate silicon $\left(\mathrm{SiO}_{4}{ }^{2-}-\mathrm{Si}\right)$, nitrite nitrogen $\left(\mathrm{NO}_{2}{ }^{-}-\mathrm{N}\right)$ and nitrate nitrogen $\left(\mathrm{NO}_{3}{ }^{-}-\mathrm{N}\right)$. Samples were dried in an oven at $105^{\circ} \mathrm{C}$ to constant mass to measure $\mathrm{MC}$, which was determined as proportion of water loss from the wet soil wet. Soil $\mathrm{pH}$ was measured by adding $10 \mathrm{ml}$ of distilled water to $4 \mathrm{~g}$ of soil and recording $\mathrm{pH}$ using a $\mathrm{pH}$ electrode (PHS-3C, Shanghai REX Instrument Factory, Shanghai, China). Analysis of organic $\mathrm{C}$ and organic $\mathrm{N}$ was performed using an Elemental Analyzer (EA3000, Euro Vector SpA, Milan, Italy). The other five properties were 
analyzed using a High Performance Microflow Analyzer (QuAAtro, SEAL Analytical GmbH, Norderstedt, Germany). The properties of five water samples were determined, including ammonium nitrogen $\left(\mathrm{NH}_{4}{ }^{+}-\mathrm{N}\right)$, silicate silicon $\left(\mathrm{SiO}_{4}{ }^{2-}-\mathrm{Si}\right)$, nitrite nitrogen $\left(\mathrm{NO}_{2}{ }^{-}-\mathrm{N}\right)$, phosphate phosphorus $\left(\mathrm{PO}_{4}^{3-}-\mathrm{P}\right)$ and nitrate nitrogen $\left(\mathrm{NO}_{3}{ }^{-}-\mathrm{N}\right)$.

\section{DNA Extraction and PCR Amplification}

Genomic DNA was extracted from the membrane filters of 8 water samples $(1000 \mathrm{ml})$ and using a PowerWater DNA Isolation Kit (MO BIO Laboratories, Inc., USA) according to the manufacturer's instructions. For soil samples, genomic DNA was extracted from $0.25 \mathrm{~g}$ of wet soil per sample (three replicates per sample). The v3-v4 region of 16S rRNA gene was amplified using primers 926R (5'-CCGTCAATTCMTTTGAGTTT-3') and 515F (5'-GTGCCAGCMGCCGCGGTAA-3'). All PCR reactions were carried out in $30 \mu \mathrm{L}$ reactions with $15 \mu \mathrm{L}$ of Phusion HighFidelity PCR Master Mix (New England Biolabs); $0.2 \mu \mathrm{M}$ of forward and reverse primers, and about $10 \mathrm{ng}$ template DNA. The PCR amplification cycle was: initial denaturation at $98^{\circ} \mathrm{C}$ for $1 \mathrm{~min}$, followed by 30 cycles of denaturation at $98^{\circ} \mathrm{C}$ for $10 \mathrm{~s}$, annealing at $50^{\circ} \mathrm{C}$ for $30 \mathrm{~s}$, and elongation at $72^{\circ} \mathrm{C}$ for $30 \mathrm{~s}$, with a final extension of $72^{\circ} \mathrm{C}$ for $5 \mathrm{~min}$. PCR products were mixed with equal volume of $1 \mathrm{X}$ loading buffer (containing SYB green) and loaded onto 2\% agarose gel for detection. Samples with a bright main strip between 400 and $450 \mathrm{bp}$ were chosen for purification with Gene JET Gel Extraction Kit (Thermo Scientific, Waltham, MA, United States).

\section{Sequencing and Data Analysis}

16S rRNA gene amplicons were sequenced on an Illumina MiSeq platform, and 300-bp paired-end reads were generated. The raw reads were deposited into the NCBI Sequence Read Archive (SRA) database (Accession Number: SRP115724). Clean data are obtained by trimming end bases and filtering low quality bases. Qiime (version 1.7.0) (Caporaso et al. 2010) was used for quality control and the chimeras were detected by the Gold database and (UCHIME Algorithm) (Edgar et al. 2011), and the chimeras sequences were removed to obtain effective data. Uparse software (Version 7.0.1001) (Edgar 2013) was used to cluster effective data into 97\% identical OTUs. The SSU rRNA database (Quast et al. 2012) of SILVA (Q. Wang et al. 2007) and Qiime was used to species annotate and analyze the representative sequences of OTU. Finally, all samples were normalized at the same sequence depth, for the subsequent alpha and beta diversity analysis.

Statistical analyses of the alpha-diversity of each sample via Chao1, Good's coverage estimator, and Shannon's index (H') were performed. The abundance-based Bray-Curtis similarity coefficient was used to examine the dissimilarity of different samples. The relationships among the bacterial communities in the 17 samples were analyzed by hierarchical clustering analysis using the R v.3.1.1 statistical software. An analysis of similarities (ANOSIM) was performed using QIIME 1.8.0 software (Caporaso et al. 2010) to determine whether different sampling sites had significantly different bacterial communities. A linear discriminant analysis effect size (LEfSe) method (Segata et al. 2011) was used to identify the significantly different bacterial groups in different sampling types (i.e., upstream water, downstream water, upstream soil, downstream soil). The relevance of environmental factors in explaining the distribution patterns of bacterial communities in different water samples or soil samples was analyzed by Bray-Curtis distance-based redundancy analysis (db-RDA) using the $\mathrm{R}$ v.3.1.1 statistical software. To determine the relationship between geochemical parameters and the microbiome, network analysis is used to detect modules (OTU subnetworks) associated with 
geochemical factors. As described by Guidi et al. (2016), the correlations of OTUs with geochemical parameters were assessed using the sparse partial least square (sPLS) (Shen Huang 2008) as implemented in the $\mathrm{R}$ package mixOmics (Rohart et al. 2017). TON and $\mathrm{PO}_{4}{ }^{3-}-\mathrm{P}$ were excluded because their concentrations were below detection levels in 7 samples. A global network of OTUs based on relative abundance from all samples was constructed and modules were identified based on relationship (i.e., the correlation of a gene to a module eigengene, which is a 1-dimensional vector that summarizes or is representative of the relative abundance of the nodes in a module) the degree and their correlation with geochemical factors was assessed using the R package WGCNA (Ghazalpour et al. 2006). Modules were then exported, analyzed, and visualized in Cytoscape 3.6 (Shannon et al. 2003).

\section{Results and Discussion}

Physical and chemical properties of samples

As shown in the table, in the water sample (Table 1), the maximum values of $\mathrm{NO}_{2}{ }^{-}-\mathrm{N}$ and $\mathrm{PO}_{4}{ }^{3-}-\mathrm{P}$ were detected in soil water under glaciers (SR02), maximum values of $\mathrm{SiO}_{4}{ }^{2-}-\mathrm{Si}$ and $\mathrm{NO}_{3}{ }^{-}-\mathrm{N}$ were detected at Lake water under the glacier (SR03), the maximum value of $\mathrm{NH}_{4}{ }^{+}-\mathrm{N}$ was seen at the sampling point glacier water (SR01). In addition to the minimum value of $\mathrm{PO}_{4}{ }^{3-}-\mathrm{P}$ seen at glacial runoff water (SR04), the minimum values of the other four nutritive salts were seen at glacier water (SR01). In the soil samples (Table 2), the maximum values of organic $\mathrm{N}$ and $\mathrm{NO}_{3}^{-}-\mathrm{N}$ were seen at soil beside glacial runoff (M4), while the maximum values of organic carbon, $\mathrm{NH}_{4}{ }^{+}-\mathrm{N}, \mathrm{SiO}_{4}{ }^{2-}-\mathrm{Si}$ and $\mathrm{NO}_{2}{ }^{-}-\mathrm{N}$ were seen at subglacial soil (M2).

Table 1 Geochemical properties of three soil samples from glacial runoff

\begin{tabular}{|c|c|c|c|c|c|c|c|c|}
\hline Sample & $\begin{array}{l}\mathrm{MC} \\
(\%)\end{array}$ & $\mathrm{pH}$ & $\begin{array}{c}\text { Organic N } \\
(\%)\end{array}$ & $\begin{array}{c}\text { Organic C } \\
(\%)\end{array}$ & $\begin{array}{c}\mathrm{NH}_{4}{ }^{+}-\mathrm{N} \\
(\mu \mathrm{g} / \mathrm{g})\end{array}$ & $\begin{array}{c}\mathrm{SiO}_{4}^{2-}-\mathrm{Si} \\
(\mu \mathrm{g} / \mathrm{g})\end{array}$ & $\begin{array}{c}\mathrm{NO}_{2}-\mathrm{N} \\
(\mu \mathrm{g} / \mathrm{g})\end{array}$ & $\begin{array}{c}\mathrm{NO}_{3}-\mathrm{N} \\
(\mu \mathrm{g} / \mathrm{g})\end{array}$ \\
\hline M2_1 & 16.19 & 8.55 & 0.189 & 0.146 & 1.56 & 10.36 & 0.33 & 0.30 \\
\hline M2_2 & 14.71 & 8.55 & 0.242 & 0.170 & 1.96 & 10.62 & 0.32 & 0.31 \\
\hline M2_3 & 15.23 & 8.55 & 0.221 & 0.161 & 1.85 & 10.56 & 0.31 & 0.30 \\
\hline Average & $15.3 \pm 0.75 a$ & $8.55 \pm 0.01 \mathrm{a}$ & $0.214 \pm 0.027$ & $0.160 \pm 0.012$ & $1.778 \pm 0.203 a$ & $10.49 \pm 0.13 a$ & $0.331 \pm 0.006 \mathrm{a}$ & $0.310 \pm 0.002 \mathrm{ab}$ \\
\hline M3_1 & 15.58 & 8.69 & 0.184 & 0.134 & 1.31 & 10.67 & 0.20 & 0.23 \\
\hline M3_2 & 18.30 & 8.50 & 0.215 & 0.138 & 1.37 & 7.63 & 0.18 & 0.21 \\
\hline M3_3 & 17.76 & 8.70 & 0.195 & 0.141 & 2.28 & 10.19 & 0.17 & 0.25 \\
\hline Average & $17.21 \pm 1.44 \mathrm{a}$ & $8.63 \pm 0.11 \mathrm{a}$ & $0.198 \pm 0.016$ & $0.138 \pm 0.035$ & $1.659 \pm 0.546 a$ & $9.50 \pm 1.63 \mathrm{ab}$ & $0.186 \pm 0.018 b$ & $0.235 \pm 0.020 \mathrm{ac}$ \\
\hline M4_1 & 18.04 & 8.58 & 0.240 & 0.153 & 1.74 & 6.56 & 0.16 & 0.64 \\
\hline M4_2 & 16.62 & 8.56 & 0.243 & 0.154 & 1.26 & 9.66 & 0.13 & 0.73 \\
\hline M4_3 & 16.39 & 8.35 & 0.218 & 0.131 & 1.58 & 6.67 & 0.18 & 0.79 \\
\hline Average & $17.02 \pm 0.89 \mathrm{a}$ & $8.50 \pm 0.13 a$ & $0.234 \pm 0.14$ & $0.146 \pm 0.013$ & $1.531 \pm 0.248 a$ & $7.64 \pm 1.76 b$ & $0.162 \pm 0.021 b$ & $0.724 \pm 0.076 a b c$ \\
\hline
\end{tabular}


Statistical significance was assessed by one-way ANOVA followed by Tukey's HSD test, and significant differences were accepted when $\mathrm{p}<0.05$ between the twogroups. The letters $\mathrm{A}, \mathrm{B}$, and $\mathrm{C}$ were used to show statistically significant differences.

Table 2 Geochemical properties of eight water samples from glacial runoff

\begin{tabular}{|c|c|c|c|c|c|c|}
\hline Sample & $\begin{array}{c}\mathrm{NH}_{4}{ }^{+}-\mathrm{N} \\
(\mu \mathrm{g} / \mathrm{g})\end{array}$ & $\begin{array}{c}\mathrm{SiO}_{4}{ }^{2-}-\mathrm{Si} \\
(\mu \mathrm{g} / \mathrm{g})\end{array}$ & $\begin{array}{c}\mathrm{NO}_{2}{ }^{-}-\mathrm{N} \\
(\mu \mathrm{g} / \mathrm{g})\end{array}$ & $\begin{array}{c}\mathrm{NO}_{3}{ }^{-}-\mathrm{N} \\
(\mu \mathrm{g} / \mathrm{g})\end{array}$ & $\begin{array}{c}\mathrm{PO}_{4}{ }^{3-}-\mathrm{P} \\
(\mu \mathrm{g} / \mathrm{g})\end{array}$ & Temperature $\left({ }^{\circ} \mathrm{C}\right)$ \\
\hline SR01 & 0.1043 & 0.0087 & 0.0029 & 0.0757 & 0.0364 & 0.5 \\
\hline SR02 & 0.3814 & 2.2778 & 0.0164 & 0.3308 & 0.0456 & 1.0 \\
\hline SR03 & 0.1773 & 3.2547 & 0.0064 & 0.3507 & 0.0230 & 3.5 \\
\hline SR04 & 2.2715 & 1.0324 & 0.0071 & 0.1239 & 0.0190 & 5.0 \\
\hline SR05 & 1.1802 & 1.4056 & 0.0055 & 0.1330 & 0.0272 & 6.0 \\
\hline SR06 & 1.0742 & 1.0268 & 0.0048 & 0.0987 & 0.0223 & 6.5 \\
\hline SR07 & 1.1783 & 0.7661 & 0.0035 & 0.0833 & 0.0263 & 7.5 \\
\hline SR08 & 1.0335 & 0.6314 & 0.0036 & 0.0760 & 0.0233 & 7.5 \\
\hline
\end{tabular}

Bacterial community structure at sampling sites

A total of 273,071 bacterial sequences and 1,293 OTUs (at the $3 \%$ evolutionary distance) were identified in the present study. The sequence number of each sample was 16,063, from which 188 to 535 OTUs were recognized. The Good's coverage estimator of the OTUs in the samples ranged from 98.99 to $99.71 \%$ (Table 3 ), indicating that the sequences sufficiently covered the diversity of bacterial populations in all the samples. According to the OTU numbers and Shannon's indices, no significant differences in bacterial richness and diversity among water samples, nor among soil samples (Table 3). However, the richness and diversity of bacteria in soil samples were significantly higher than that in water samples from glacial runoff. The species accumulation boxplot (Fig. S1) saturates with all seventeen samples, indicating the species diversity of the study sites should be well represented by these samples.

In the present study, the high level of Shannon diversity indices $\left(H^{\prime}=3.07-4.68\right)$ and the identification of 188-535 OTUs suggest high richness and diversity of bacterial communities in the soils samples and water samples from glacial runoff areas (Table 3). By comparison, Gutiérrez et al. (2015) used high-throughput sequencing to report an OTU of 47-589 for bacterial communities in glacial meltwater runoff from the Southern Patagonian ice sheet. The bacterial richness observed in this 
study was somewhat similar to that observed in meltwater from the Southern Patagonian ice sheet. The overall trend of OTU increases from upstream to downstream, similar to the trend of bacterial diversity in glacial meltwater observed in Baishui Glacier (Sajjad et al. 2021). In addition, the OTU of glacial soil was higher than that of glacial runoff.

Proteobacteria, Bacteroidetes and Actinobacteria in water and soil samples of all sampling points are common (Fig. 2). It is worth noting that in soil samples, Actinobacteria and Acidobacteria abundance is higher than the water samples. In addition, the composition of the bacterial community upstream of glacial runoff was somewhat different from that downstream. The abundance of Actinobacteria and Firmicutes in the upstream sampling points (SR01, SR02, SR03) of glacial runoff was higher than that in the downstream sampling points of glacial runoff (SR04, SR05, SR06, SR07, SR08). The abundance of Cyanobacteria in the downstream sampling sites of glacial runoff is higher than that in the upstream sampling sites. At the level of genus classification, Proteobacteria in the most abundant sequence belongs to the Gammaproteobacteria, Betaproteobacteria and Alphaproteobacteria (Fig. 3). The abundance of Betaproteobacteria and Gammaproteobacteria in the upstream sampling points of glacial runoff was higher than that in the downstream sampling points of glacial runoff. However, the abundance of Alphaproteobacteria and Flavobacteria in the downstream sampling points of glacial runoff is higher than that in the upstream sampling points of glacial runoff. In addition, the abundance of Actinobacteria and Acidimicrobiia was more increased in soil samples than in water samples.

There were differences in the main bacterial groups in the upper and lower reaches of glacial meltwater runoff. The abundance of Actinobacteria and Firmicutes was higher upstream of glacial runoff than in the downstream of glacial runoff (Fig. 2). Actinobacteria are common in the High Arctic, but they tend to thrive in cold, dry environments such as glacial soil compared to coastal areas downstream of glacial runoff. This phenomenon can be explained by their spore formation ability, tolerance to ultraviolet radiation, and other environmental adaptations that ensure their survival in harsh conditions (Katz Baltz 2016; Undabarrena et al. 2016). Some genera of Actinobacteria also produce some essential bioactive compounds, including anti-fungal compounds and anti-parasitic compounds (Berdy 2005). The upstream of glacial runoff is closer to the glacial soil, so the abundance of Actinobacteria may be increased through the flow of soil into the glacial runoff. Some studies have shown that Firmicutes are typical Arctic tundra aerobic bacteria. For example, many studies have isolated Firmicutes from the Arctic tundra of Siberia, Svalbard and the Canadian Arctic highlands by culturable methods (Hansen et al. 2007; Steven et al. 2007; Vishnivetskaya et al. 2006). This suggests that Firmicutes are relatively common in the glacial foreland, and our results are consistent with previous ones. Several taxa in Firmicutes are endospore-forming and can cope with potentially harsh conditions (Filippidou et al. 2015). In addition, at the class level, the abundance of Betaproteobacteria and Gammaproteobacteria was higher than that downstream of glacial runoff (Fig. 3). This is because Betaproteobacteria and Gammaproteobacteria are suitable for growth in nutrient-rich conditions (Aislabie et al. 2009). At the same time, our data show that the concentration of most nutrients upstream of glacial runoff is higher than that in the downstream of glacial runoff (Table 2). We analyzed that the possible reason is that the nutrient enrichment in the upstream passes through the downstream, and after reaching the estuary, the nutrient concentration decreases due to dilution.

In the downstream of glacial runoff, the abundance of Cyanobacteria was higher. At the genus level, the abundance of Alphaproteobacteria was higher than that in the upstream of glacial runoff. Cyanobacteria are typical prokaryotes in the ocean. Generally, cyanobacteria colonize in warm 
environments (Ali et al. 2021). Therefore, the temperature is an important factor affecting the abundance of cyanobacteria, and our data show that the temperature downstream of glacial runoff is significantly higher than that upstream (Table 2). Cyanobacteria play an important role in promoting the ocean nitrogen cycle ( $\mathrm{Li}$ et al. 2018), and Cyanobacteria are not only critical primary producers but also responsible for nitrogen fixation in the ocean (Church et al. 2005; Moisander et al. 2010; Montoya et al. 2004). Alphaproteobacteria is thought to be a diazotrophic community, and it's been reported that Alphaproteobacteria predominate in the open ocean, such as the northern South China Sea, the southern Indian Ocean and the eastern tropical South Pacific (Cheung et al. 2017; Moisander et al. 2014; Shiozaki et al. 2014).

It can be seen from the data that the OTU number and Shannon index of the soil are higher than that of the water sample (Table 3), indicating that the bacterial diversity of the glacial soil is higher than that of the glacial runoff. This could be due to several reasons, such as the fact that the soil provides a nutrient-rich solid surface for bacteria to survive while the interaction with surrounding rocks and soil increases the concentration of heavy metals in glacial runoff and reduces bacterial diversity (Sajjad et al. 2021). There is a specific relationship between the bacterial community composition of glacial soil and that of glacial runoff. For example, the abundance of Actinobacteria in glacial soils is somewhat similar to the design of bacterial communities upstream from glacial runoff (Fig. 2), and this may be due to the continuous interaction between water and soil and selective migration of bacteria to water (Sajjad et al. 2021). Yang et al. (2016) and Luláková et al. (2019) reported Actinobacteria in glacial soil and permafrost environments, respectively. Some members of the Actinobacteria form hyphae, which help them get nutrients and water to survive. In contrast, the abundance of Acidobacteria in soil was significantly higher than in water samples. Previous studies have shown that Acidobacteria is ubiquitous and abundant members of the soil bacterial community, and Acidobacteria tend to be enriched in soils with $\mathrm{pH}$ deviating from neutral (Jones et al. 2009).

Table 3 Summary data for Miseq sequencing data from the 17 samples in the present study.

\begin{tabular}{cccccc}
\hline $\begin{array}{c}\text { Sample } \\
\text { code }\end{array}$ & $\begin{array}{c}\text { Number of } \\
\text { sequence }\end{array}$ & $\begin{array}{c}\text { Number of } \\
\text { OTUs }\end{array}$ & Chao 1 & $\begin{array}{c}\text { Good's coverage } \\
\text { estimator (\%) }\end{array}$ & $\begin{array}{c}\text { Shannon's } \\
\text { Index }\end{array}$ \\
\hline SR01 & 16063 & 263 & 393 & 99.42 & 3.08 \\
SR02 & 16063 & 301 & 437 & 99.27 & 3.07 \\
SR03 & 16063 & 285 & 394 & 99.34 & 3.14 \\
SR04 & 16063 & 225 & 375 & 99.44 & 3.22 \\
SR05 & 16063 & 488 & 682 & 98.99 & 4.23 \\
SR06 & 16063 & 353 & 530 & 99.22 & 3.87 \\
SR07 & 16063 & 259 & 370 & 99.49 & 3.49 \\
SR08 & 16063 & 188 & 237 & 99.71 & 3.33 \\
M2_1 & 16063 & 443 & 544 & 99.30 & 4.03 \\
M2_2 & 16063 & 366 & 486 & 99.33 & 3.81 \\
M2_3 & 16063 & 413 & 547 & 99.24 & 3.70 \\
M3_1 & 16063 & 494 & 623 & 99.17 & 4.06 \\
M3_2 & 16063 & 507 & 632 & 99.21 & 4.29 \\
M3_3 & 16063 & 480 & 599 & 99.19 & 4.13 \\
M4_1 & 16063 & 478 & 587 & 99.32 & 4.43 \\
M4_2 & 16063 & 515 & 603 & 99.33 & 4.68 \\
M4_3 & 16063 & 535 & 620 & 99.34 & 4.62 \\
\hline
\end{tabular}


\# Defined at the cutoff 3\% difference in sequence. Statistical significance was assessed by one-way ANOVA followed by Tukey's HSD test, and significant differences were accepted when $\mathrm{p}<0.05$ between the two groups.

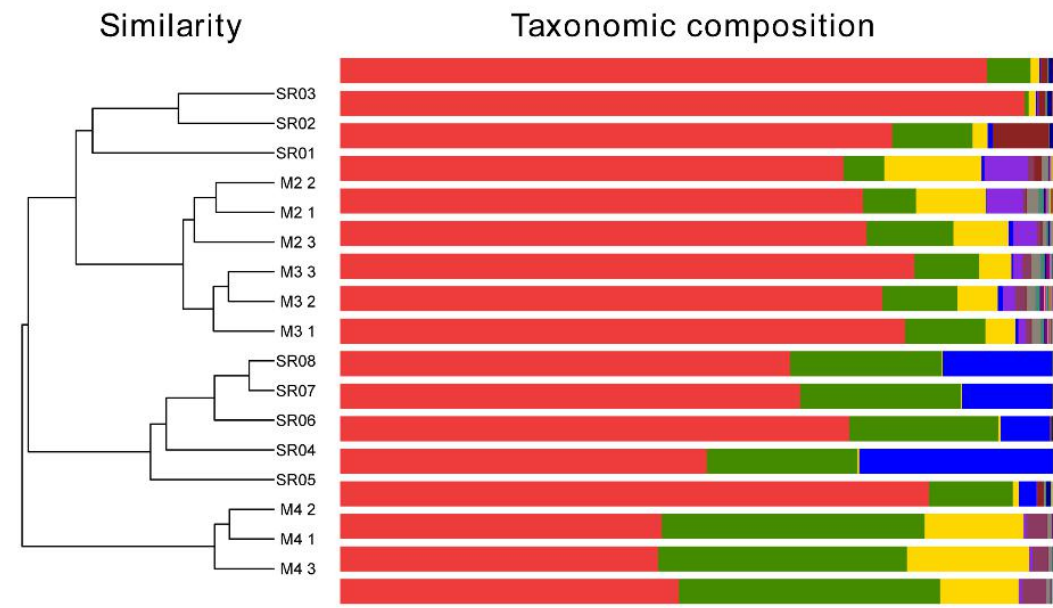

Fig.2 Bar charts of the top 21 phyla from 17 samples and cluster analysis of bacterial communities based on OTU abundance.

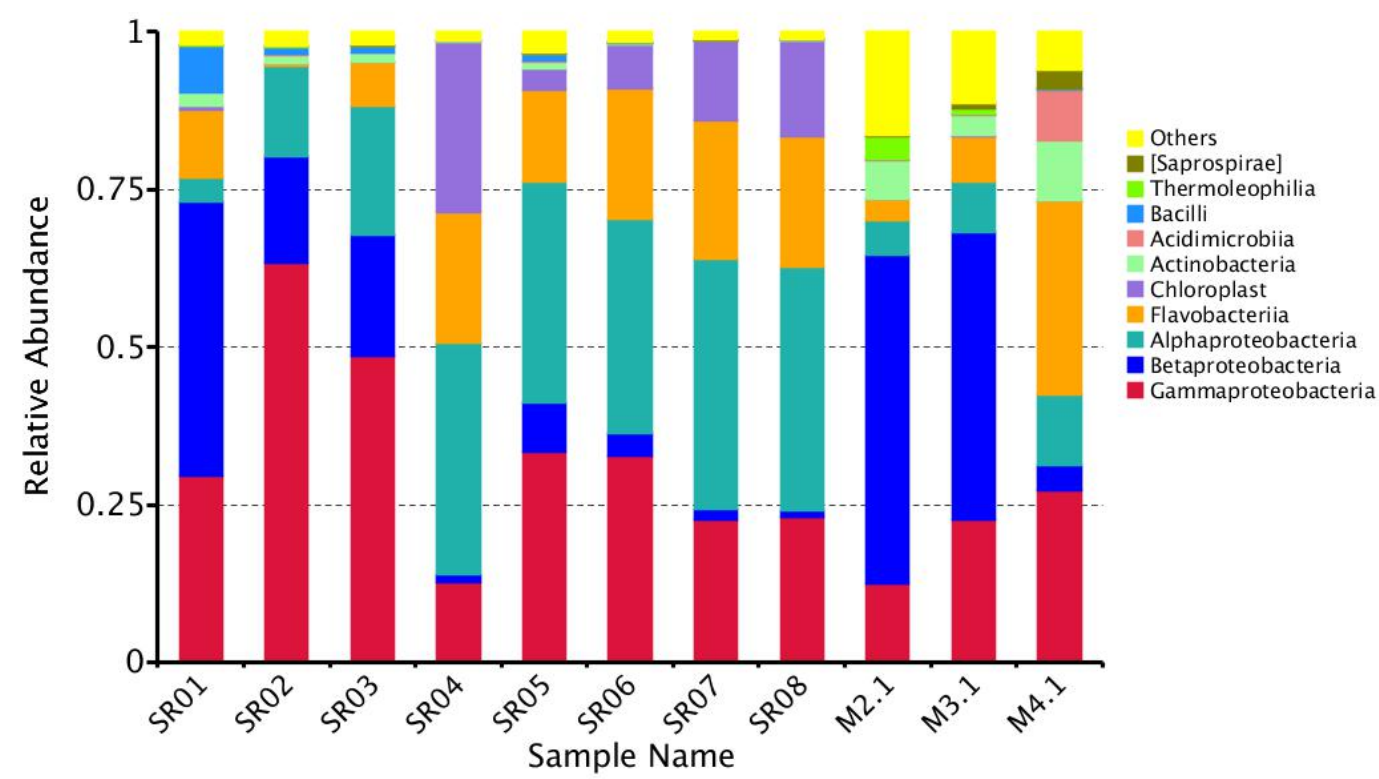

Fig.3 The top 10 abundant genera in the sampling sites.

Bacterial differences in different sampling environments

Non-metric Multidimensional Scaling (NMDS) was used to check for differences between samples. As expected, the soil samples were separated from the water samples, and the upstream 
samples from the glacier runoff were isolated from the downstream samples (Fig. 4). We divided the samples into four groups according to the difference, namely GroupA (SR01, SR02 and SR03), GroupB (SR04, SR05, SR06, SR07 and SR08), GroupC (M4_1, M4_2 and M4_3) and GroupD (M2_1, M2_2, M2_3, M3_1, M3_2 and M3_3). This dissimilarity in samples was close to an Unweighted Pair-group Method with Arithmetic Mean (UPGMA) tree based on the weighted UniFrac distance (Fig. 5). An ANOSIM test $(R=0.992, P=0.001)$ supported significantly different bacterial communities between the four groups (Fig. 6). A Venn diagram demonstrated that OTUs differed among the four groups (Fig. 7). The number of site-specific OTUs ranged from 20 (GroupA) to 307 (GroupD). Only 116 in 1,293 OTUs were shared by all four groups.

To compare the differences in bacterial composition and structure under different environmental types, LEfSe (LDA Effect Size) analysis was conducted on four groups of sampling sites. Based on the LEfSe results, 63 taxa showed LDA score (Linear Discriminant Analysis) greater than 4 (the cutoff for significance test) in the 17 samples (Fig. 8). GroupD has the largest number of taxa, 22 out of 63 (35\%), more than the other group. Enriched taxa typical in GroupD mainly includes the Bacteroidetes, Flavobacteriia, Flavobacteriaceae and Flavobacteriales. LDA score analysis showed that members belonging to Flavobacterium and Sphingobacterium were more prominent in the soil (Fig. 8). Flavobacterium and Sphingobacterium members are widely distributed in soils and have been isolated from polar and rhizosphere soils (Chaudhary et al. 2019; Du et al. 2015; R. Zhang et al. 2019).

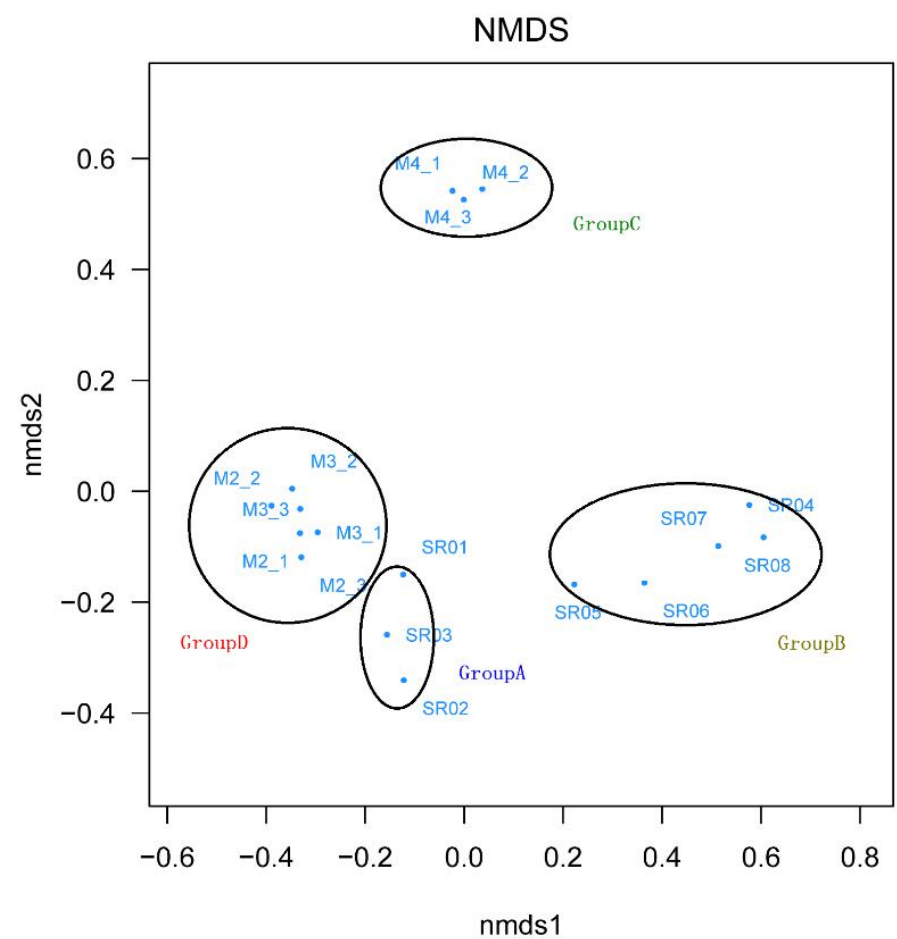

Fig.4 Non-metric Multi-dimensional Scaling analysis of the samples. 


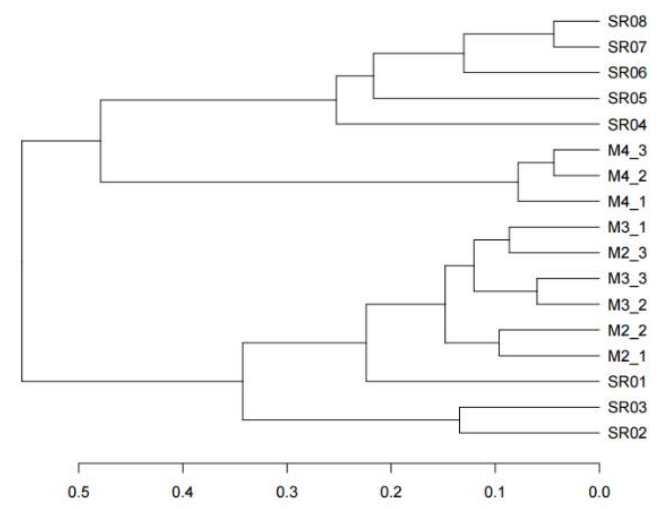

Fig.5 UPGMA Tree of the 17 samples.

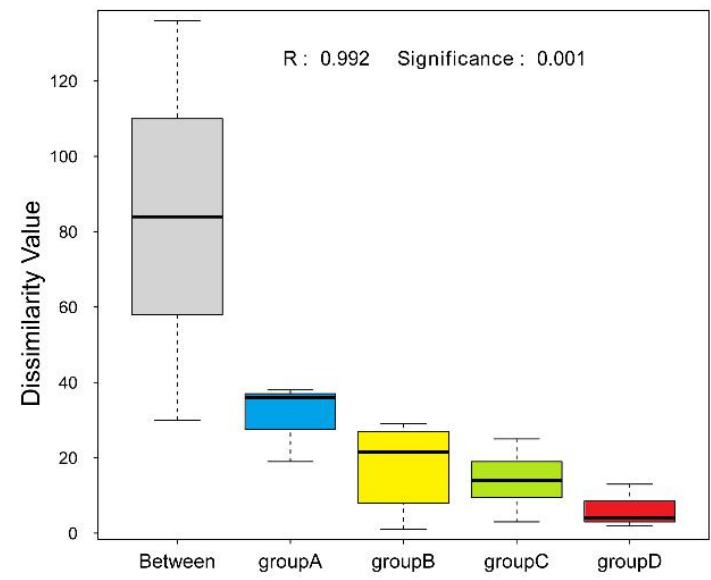

Fig.6 Analysis of similarities (ANOSIM) of the four groups in the present study.

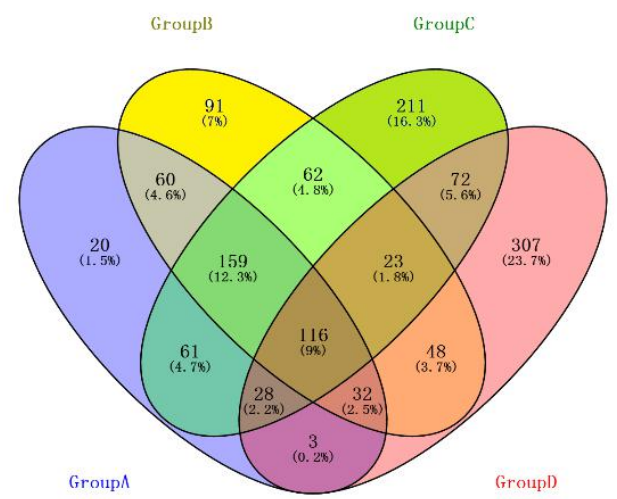

Fig.7 A Venn diagram displaying the degree of overlap of bacterial OTUs (at the 3\% evolutionary distance) among the four groups. 


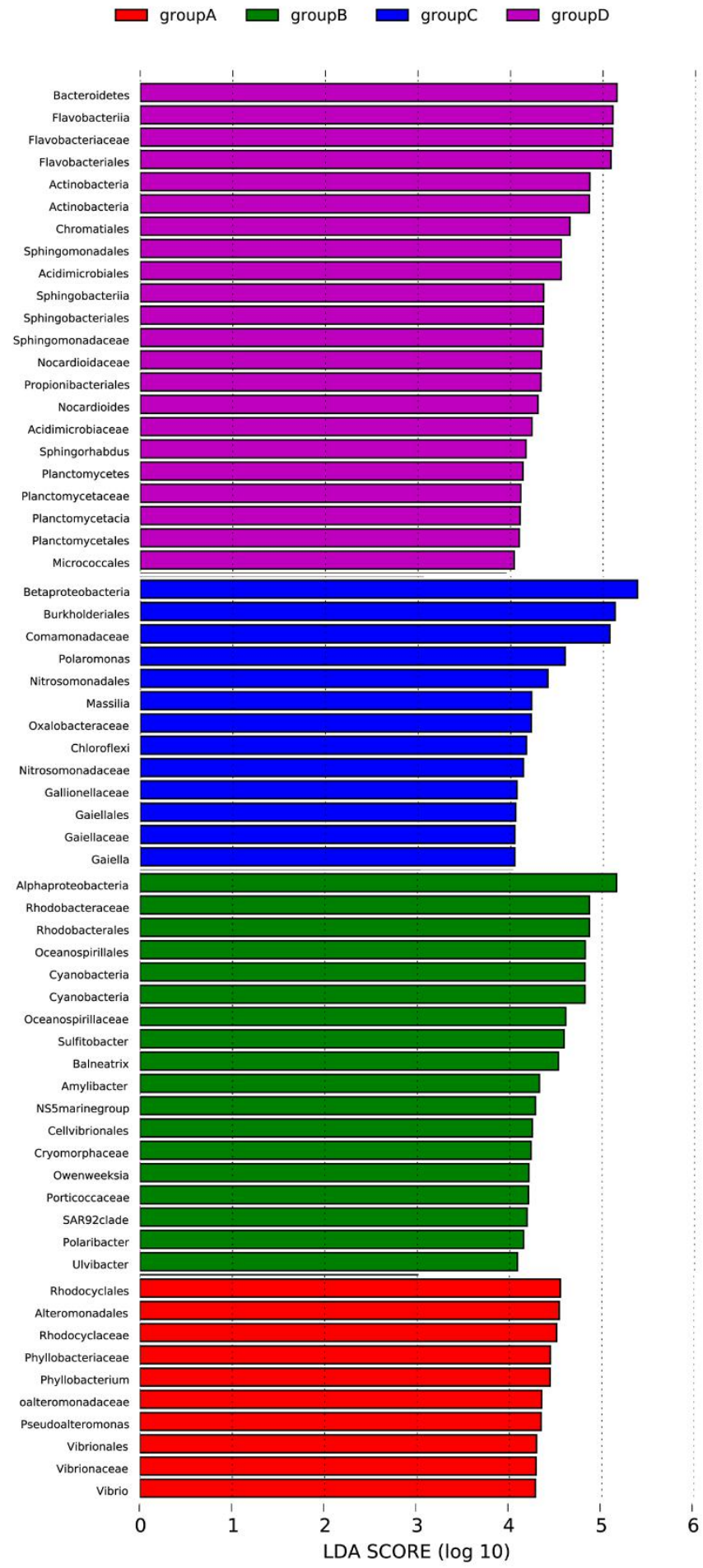

Fig.8 The LDA score distribution histogram is to search for Biomarker (Segata et al. 2011), which has a statistically significant difference between group and group, at all classification levels, and used the LDA score distribution histogram to show the species with LDA score larger than 4 in the present study. 


\section{Correlation between geochemical properties and bacterial community structure}

Distance-based redundancy analysis (db-RDA) and Monte Carlo permutation tests were performed to examine the relationship between the geochemical properties and bacterial community composition. In the RDA analysis of soil samples, the M2 samples were positively correlated with all environmental factors except $\mathrm{pH}$. M3 is positively correlated with $\mathrm{pH}, \mathrm{SiO}_{4}{ }^{2-} \mathrm{Si}$ and $\mathrm{NH}_{4}{ }^{+}-\mathrm{N}$. M4 is positively correlated with Organic $\mathrm{N}$ (Fig. 9a). Among all the geochemical properties, $\mathrm{NO}_{2}^{-}-\mathrm{N}\left(\mathrm{r}^{2}=\right.$ $0.9329, \mathrm{P}<0.05)$ is one of the most critical factors affecting the composition of soil bacterial community (Fig. 9a and Table 4). In water sample RDA analysis, SR01 was positively correlated with $\mathrm{PO}_{4}{ }^{3-}-\mathrm{P}, \mathrm{SR} 02$, SR03, SR05 and SR06 were positively correlated with $\mathrm{NO}_{3}{ }^{-}-\mathrm{N}, \mathrm{NO}_{2}{ }^{-}-\mathrm{N}$ and $\mathrm{SiO}_{4}{ }^{2-} \mathrm{Si}$, SR04, SR07 and SR08 are positively associated with $\mathrm{NH}_{4}{ }^{+}-\mathrm{N}$ (Fig. 9b). Among all the geochemical properties, $\mathrm{NO}_{3}^{-}-\mathrm{N}\left(\mathrm{r}^{2}=0.8196, \mathrm{P}<0.05\right)$ is one of the most important factors affecting the bacterial community composition of water samples (Fig. $9 \mathrm{~b}$ and Table 5).

The combinations of the six different Geochemical factors were significantly correlated with the composition of soil bacterial community and water bacterial community, respectively. In this study, $\mathrm{NO}_{2}-\mathrm{N}(\mathrm{p}<0.05)$ was the best predictor of soil bacterial community composition. Furthermore, organic $\mathrm{C}(\mathrm{p}<0.05)$ showed a significant correlation with the bacterial community composition (Fig. 9a and Table 4). In the previous studies, soil $\mathrm{pH}$ was found to be the most influential soil properties to determine the bacterial community structure in subarctic tundra soil (Kim et al. 2014; Shi et al. 2015), whereas Ganzert et al. (2011) reported that the soil bacterial community composition was most affected by total carbon and total nitrogen contents and soil physical factors such as moisture, but not $\mathrm{pH}$. Interestingly, $\mathrm{NO}_{3}^{-}-\mathrm{N}$ was the best predictor of bacterial community composition in the water sample (Fig. 9b and Table 5). This suggests that nitrate-nitrogen is an essential factor affecting the bacterial community composition in the habitat of Midre Lovénbreen glacier. On the one hand, high gene abundances of nirS (nitrite reductase) and narG (nitrate reductase) have been observed in glacial foreland (Kandeler et al. 2006); on the other hand, peak nitrate reductase activity was detected in the central Alpine glacial foreland (Deiglmayr et al. 2006).

a

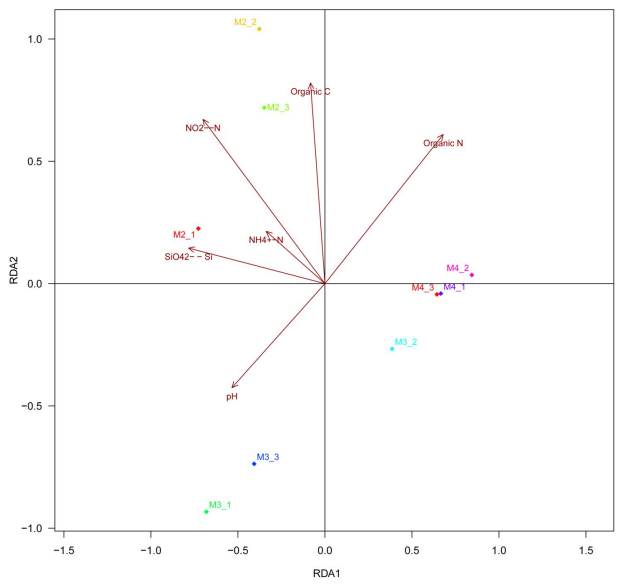

b

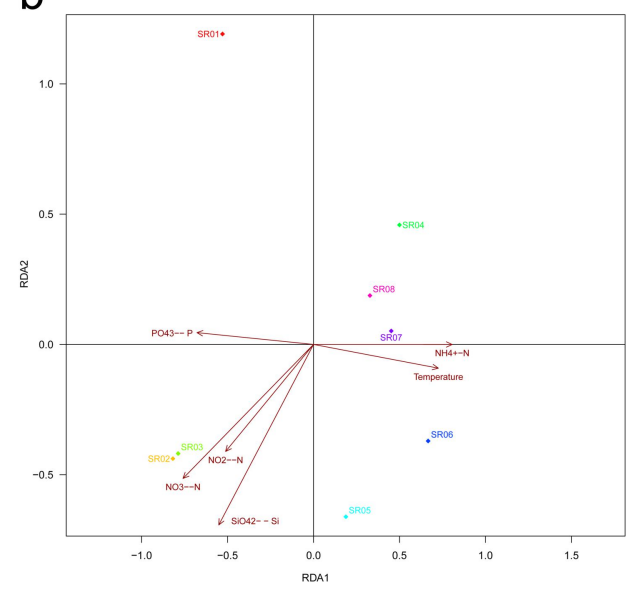

Fig.9 Distance-based redundancy analysis revealed the correlation between bacterial community and geochemical properties of soil samples (a) and water samples (b). 
Table 4 A Monte Carlo permutation test for environmental factors and bacterial community composition of soil samples.

\begin{tabular}{ccccc}
\hline & RDA1 & RDA2 & $\mathrm{r}^{2}$ & P value \\
\hline Organic C & -0.26842 & 0.96330 & 0.6091 & 0.086 \\
Organic $\mathrm{N}$ & 0.72509 & 0.68866 & 0.5482 & 0.084 \\
$\mathrm{pH}$ & -0.78321 & -0.62176 & 0.3064 & 0.336 \\
$\mathrm{NH}_{4}-\mathrm{N}$ & -0.78229 & 0.62292 & 0.1536 & 0.608 \\
$\mathrm{SiO}_{4}{ }^{2-} \mathrm{Si}$ & -0.92943 & 0.36900 & 0.5406 & $0.044^{*}$ \\
$\mathrm{NO}_{2}-\mathrm{N}$ & -0.69063 & 0.72321 & 0.9329 & $0.020^{*}$ \\
\hline
\end{tabular}

*Correlation is significant at the 0.05 level.

$P$ values based on 999 permutations.

Table 5 A Monte Carlo permutation test for environmental factors and bacterial community

\begin{tabular}{ccccc}
\multicolumn{5}{c}{ composition of water samples. } \\
\hline $\mathrm{NH}_{4}{ }^{+}-\mathrm{N}$ & 0.999644 & $\mathrm{RDA} 2$ & $\mathrm{r}^{2}$ & P value \\
$\mathrm{SiO}_{4}{ }^{2-}-\mathrm{Si}$ & -0.605191 & -0.796081 & 0.6072 & 0.096 \\
$\mathrm{NO}_{3}{ }^{-}-\mathrm{N}$ & -0.806937 & -0.590638 & 0.7781 & $0.024^{*}$ \\
$\mathrm{NO}_{2}{ }^{-}-\mathrm{N}$ & -0.758175 & -0.652051 & 0.4220 & $0.006^{* *}$ \\
$\mathrm{PO}_{4}{ }^{3-}-\mathrm{P}$ & -0.999038 & 0.0438842 & 0.4300 & 0.172 \\
Temperature & 0.994383 & -0.105840 & 0.4973 & 0.216 \\
\hline
\end{tabular}

*Correlation is significant at the 0.05 level.

**Correlation is significant at the 0.01 level.

P values based on 999 permutations.

Weighted correlation network analysis of core bacteria

Weighted correlation network analysis was carried out on the OTU with the top 300 weight values, and the expression relationship between OTU could be shown through the Weighted Correlation Network Analysis. If the expression trend of some OTU varies with the same trend between different treatments, then we consider these genes to be on a pathway, thus identifying the core OTU across the entire network. As can be seen from the figure (Fig. 10), the core OTU of soil samples is different from that of water samples. Occupy the central position in water samples OTU, including OTU983 (Sporichthyaceae), OTU599 (Cyanobacteria), OTU94 (Oceanospirillales), OTU150 (SAR11 clade, Alphaproteobacteria), OTU101 (Beutenbergia), OTU451 (Chloroplast) and OTU1195 (Nitrospiraceae). Occupy the central role in soil sample OTU including OTU49 (Flavobacteriaceae), OTU53 (Gillisia), OTU82 (Paraglaciecola), OTU4 (Perlucidibaca), OTU27 (Nocardioides) and OTU42 (Maribacter).

To further discuss the relationship between the core bacteria and physical and chemical factors and determine their correlation, we performed Pearson correlation analysis on the core OTU obtained from network analysis and physical and chemical factors (Table 6 and Table 7). In water samples, OTU101, OTU150 and OTU1195 were extremely significantly correlated with $\mathrm{NO}_{3}{ }^{-}-\mathrm{N}$, and OTU451 was significantly correlated with $\mathrm{NH}_{4}{ }^{+}-\mathrm{N}$. In soil samples, OTU4, OTU27, OTU42, OTU49, OTU53 and OTU82 were extremely significantly correlated with $\mathrm{NO}_{2}{ }^{-}-\mathrm{N}$.

WGCNA analysis showed that the core bacteria in water samples was quite different from that in soil samples (Fig. 10). Most of the core bacteria in water samples were related to Nitrospirae and 
Cyanobacteria, while most of the core bacteria in soil samples were typical soil bacteria such as Flavobacteriaceae. Nitrospirae and Cyanobacteria belong to nitrogen-fixing organisms. Nitrogen-fixing by diazotrophic microorganisms is an essential strategy for microorganisms to survive in nitrogen-deficient water (Montoya et al. 2004). In addition, most of the core bacteria in water samples have a strong correlation with $\mathrm{NO}_{3}{ }^{-} \mathrm{N}$, while most of the core bacteria in soil samples have a strong correlation with $\mathrm{NO}_{2}^{-}-\mathrm{N}$ (Table 6 and Table 7). This is highly consistent with the results of Distance-based redundancy analysis (Fig. 9), which fully indicates that $\mathrm{NO}_{3}{ }^{-}-\mathrm{N}$ is the best predictor of bacterial diversity in water samples, and $\mathrm{NO}_{2}-\mathrm{N}$ is the best predictor of bacterial diversity in soil samples.
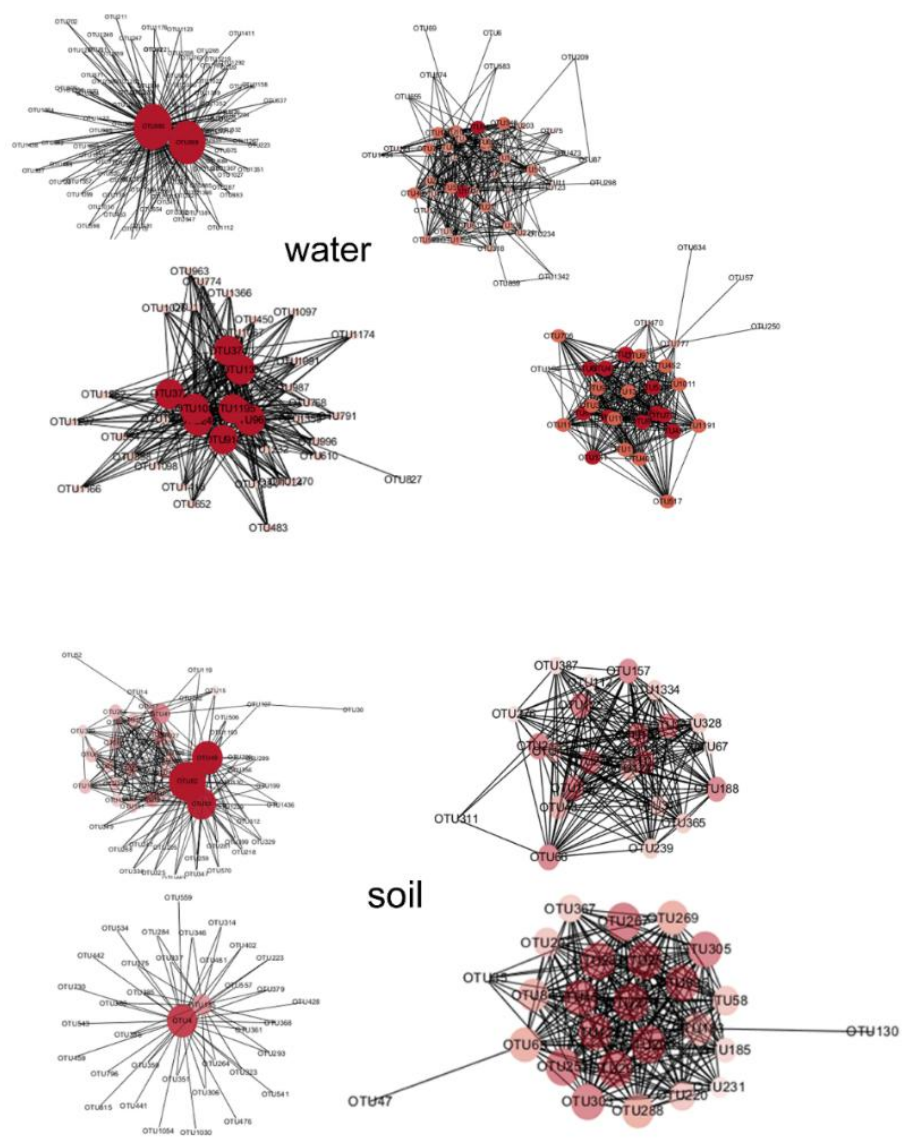

Fig.10 Weighted correlation network analysis of core bacteria in water and soil samples (The darker the color, the larger the size, and the stronger the correlation of OTU). 
Table 6 Correlation between core OTU and geochemical factors in water samples.

\begin{tabular}{cccccccc}
\hline OTU & & $\mathrm{NH}_{4}{ }^{+}-\mathrm{N}$ & $\mathrm{SiO}_{4}{ }^{2-}-\mathrm{Si}$ & $\mathrm{NO}_{2}{ }^{-}-\mathrm{N}$ & $\mathrm{NO}_{3}{ }^{-}-\mathrm{N}$ & $\mathrm{PO}_{4}{ }^{3-}-\mathrm{P}$ & Temperature \\
\hline OTU94 & $\mathrm{r}$ & 0.340 & -0.241 & -0.468 & -0.369 & -0.318 & 0.703 \\
& $\mathrm{P}$ & 0.410 & 0.565 & 0.242 & 0.369 & 0.443 & 0.052 \\
OTU101 & $\mathrm{r}$ & -0.310 & 0.386 & 0.608 & $0.941^{* *}$ & $0.812^{*}$ & -0.539 \\
& $\mathrm{P}$ & 0.454 & 0.345 & 0.110 & 0.003 & 0.014 & 0.168 \\
OTU150 & $\mathrm{r}$ & 0.305 & -0.164 & -0.377 & $-0.796^{* *}$ & -0.251 & 0.585 \\
& $\mathrm{P}$ & 0.462 & 0.698 & 0.357 & 0.006 & 0.548 & 0.128 \\
OTU451 & $\mathrm{r}$ & $0.825^{*}$ & -0.126 & -0.174 & 0.039 & -0.456 & 0.124 \\
& $\mathrm{P}$ & 0.012 & 0.766 & 0.681 & 0.927 & 0.256 & 0.770 \\
OTU983 & $\mathrm{r}$ & 0.093 & -0.113 & -0.223 & -0.188 & -0.002 & 0.137 \\
& $\mathrm{P}$ & 0.827 & 0.789 & 0.596 & 0.656 & 0.996 & 0.746 \\
OTU1195 & $\mathrm{r}$ & -0.010 & -0.127 & -0.189 & -0.175 & 0.098 & -0.012 \\
& $\mathrm{P}$ & 0.980 & 0.764 & 0.654 & 0.678 & 0.818 & 0.977 \\
& $\mathrm{r}$ & -0.357 & 0.467 & 0.682 & $0.951 * *$ & $0.797 *$ & -0.562 \\
\hline
\end{tabular}

*Correlation is significant at the 0.05 level.

$* *$ Correlation is significant at the 0.01 level.

Table 7 Correlation between core OTU and geochemical factors in soil samples.

\begin{tabular}{cccccccccc}
\hline $\begin{array}{c}\text { OTU } \\
\text { number }\end{array}$ & & $\mathrm{MC}$ & $\mathrm{pH}$ & $\mathrm{TON}$ & $\mathrm{TOC}$ & $\mathrm{NH}_{4}{ }^{+}-\mathrm{N}$ & $\mathrm{SiO}_{4}{ }^{2-}-\mathrm{Si}$ & $\mathrm{NO}_{3}{ }^{-}-\mathrm{N}$ & $\mathrm{NO}_{2}{ }^{-}-\mathrm{N}$ \\
\hline OTU4 & $\mathrm{r}$ & 0.099 & -0.569 & 0.484 & -0.192 & -0.377 & -0.489 & -0.549 & $0.940^{* *}$ \\
& $\mathrm{P}$ & 0.801 & 0.110 & 0.186 & 0.621 & 0.318 & 0.181 & 0.126 & 0.006 \\
OTU27 & $\mathrm{r}$ & 0.276 & -0.288 & $0.670^{*}$ & 0.062 & -0.326 & -0.520 & -0.585 & $0.909^{* *}$ \\
& $\mathrm{P}$ & 0.473 & 0.453 & 0.048 & 0.874 & 0.392 & 0.152 & 0.098 & 0.001 \\
OTU42 & $\mathrm{r}$ & 0.279 & -0.359 & 0.640 & -0.018 & -0.330 & -0.574 & -0.616 & $0.946^{* *}$ \\
& $\mathrm{P}$ & 0.468 & 0.343 & 0.063 & 0.964 & 0.386 & 0.106 & 0.077 & 0.004 \\
OTU49 & $\mathrm{r}$ & 0.239 & -0.421 & 0.614 & -0.063 & -0.348 & -0.566 & -0.613 & $0.965^{* *}$ \\
& $\mathrm{P}$ & 0.536 & 0.259 & 0.079 & 0.872 & 0.358 & 0.112 & 0.079 & 0.002 \\
OTU53 & $\mathrm{r}$ & 0.238 & -0.429 & 0.611 & -0.069 & -0.346 & -0.572 & -0.612 & $0.968^{* *}$ \\
& $\mathrm{P}$ & 0.537 & 0.249 & 0.080 & 0.860 & 0.361 & 0.108 & 0.080 & 0.003 \\
OTU82 & $\mathrm{r}$ & 0.221 & -0.432 & 0.605 & -0.072 & -0.360 & -0.547 & -0.609 & $0.964 * *$ \\
& $\mathrm{P}$ & 0.568 & 0.245 & 0.085 & 0.855 & 0.341 & 0.128 & 0.082 & 0.006 \\
\hline
\end{tabular}

*Correlation is significant at the 0.05 level.

${ }^{* *}$ Correlation is significant at the 0.01 level.

\section{Conclusion}

Glacier habitats are recognized as great repositories of microbial ecology. But most of the major 
taxa in glacial habitats are unculturable. In addition, the changes of bacterial community composition in the upstream and downstream of glacial runoff and the relationship between glacial runoff and soil are not fully understood. In this study, the bacterial diversity and its physicochemical drivers in the runoff area of Midre Lovénbreen glacier in Svalbard were comprehensively evaluated using high-throughput sequencing technology. Arctic microorganisms are susceptible to the environmental changes of the Arctic ecosystem, so understanding the Arctic microbial community is of great significance for predicting Arctic warming, and the glacial ecosystem is good sentinels of climate change in the Arctic.

This study revealed bacterial diversity and community structure in soil and meltwater runoff of Midre Lovénbreen glacier. Despite the harsh ecological environment of the glacier, but the study found a high diversity of bacteria, including Proteobacteria, Bacteroidetes, and Actinobacteria. There are some differences in bacterial community composition between the upper and lower reaches of glacial runoff. In addition, the abundance of OTU in glacial soil was significantly higher than that in the glacial runoff, and there are many typical soil bacteria in glacier soil compared to glacier runoff. Studies have shown that geochemical factors are the main driving factors of bacterial community structure in glacial habitats. The most significant factors affecting glacial runoff and glacial soil bacterial community structure are closely related to nitrate nitrogen.

\section{Acknowledgements}

We thank the First Oceanographic Institute, Ministry of Natural Resources for supporting this study.

\section{Declarations}

\section{Funding}

This research was funded by the National Natural Science Foundation of China (No.41776198), the Natural Foundation of Shandong Province National (No.ZR2020KC036), the Key R\&D Program of China (2018YFC1406700), and Basic Scientific Fund for National Public Research Institutes of China (Nos.GY0219Q10).

\section{Conflicts of interest}

The authors declare that they have no conflicts of interest.

\section{Availability of data and material}

Raw data have been deposited into the NCBI Sequence Read Archive (SRA) database (Accession Number: SRP115724).

\section{Code availability}

Not applicable.

\section{Authors' contributions}

Conceptualization: NW, WH, BZ, JZ and JL; methodology: BZ; software: WH; validation: LL, YQ and FZ; formal analysis: JZ; investigation: NW; resources: NW and JL; data curation: LL, QL and LW; writing — original draft preparation: LL; writing — review and editing: NW, WH and LL; visualization: LL, YQ and LW; supervision: WH, FZ and QL; project administration: NW; funding acquisition: NW.

\section{Ethics approval}

Not applicable.

\section{Consent to participate}

Not applicable.

\section{Consent for publication}


All authors read and approved the final version of the manuscript.

\section{References}

Aislabie J, Jordan S, Ayton J, Klassen J, Barker G, Turner S (2009) Bacterial diversity associated with ornithogenic soil of the Ross Sea region, Antarctica. Canadian journal of microbiology 55(1): 21-36. http://doi.org/doi:10.1139/w08-126

Ali B, Sajjad W, Ghimire PS, Khan S, Din G, Kang S (2021) Culture independent diversity of bacterial communities indigenous to lower altitude at Laohugou glacial environment. Geomicrobiology Journal 38(1): 1-13. http://doi.org/doi:10.1080/01490451.2020.1797946

Anesio AM, Lutz S, Chrismas NA, Benning LG (2017) The microbiome of glaciers and ice sheets. npj Biofilms and Microbiomes 3(1): 1-11. http://doi.org/doi:10.1038/s41522-017-0019-0

Berdy J (2005) Bioactive microbial metabolites. The Journal of antibiotics 58(1): 1-26. http://doi.org/doi:10.1038/ia.2005.1

Bhatia M, Sharp M, Foght J (2006) Distinct bacterial communities exist beneath a high Arctic polythermal glacier. Applied and Environmental Microbiology 72(9): 5838-5845. http://doi.org/doi:10.1128/AEM.00595-06

Björnsson H, Gjessing Y, Hamran S-E, Hagen JO, LiestøL O, Pálsson F, et al. (1996) The thermal regime of sub-polar glaciers mapped by multi-frequency radio-echo sounding. Journal of Glaciology 42(140): 23-32. http://doi.org/doi:10.1017/S0022143000030495

Caporaso JG, Kuczynski J, Stombaugh J, Bittinger K, Bushman FD, Costello EK, et al. (2010) QIIME allows analysis of high-throughput community sequencing data. Nature methods 7(5): 335-336. http://doi.org/doi:10.1038/NMETH.F.303

Chaudhary DK, Dahal RH, Kim J (2019) Flavobacterium silvisoli sp. nov., isolated from forest soil. International journal of systematic and evolutionary microbiology 69(9): 2762-2766. http://doi.org/doi:10.1099/ijsem.0.003551

Cheung S, Suzuki K, Saito H, Umezawa Y, Xia X, Liu H (2017) Highly heterogeneous diazotroph communities in the Kuroshio Current and the Tokara Strait, Japan. PloS one 12(10): e0186875. http://doi.org/doi:10.1371/journal.pone.0186875

Church MJ, Short CM, Jenkins BD, Karl DM, Zehr JP (2005) Temporal patterns of nitrogenase gene (nifH) expression in the oligotrophic North Pacific Ocean. Applied and environmental microbiology 71(9): 5362-5370. http://doi.org/doi:10.1128/AEM.71.9.5362-5370.2005

Deiglmayr K, Philippot L, Tscherko D, Kandeler E (2006) Microbial succession of nitrate-reducing bacteria in the rhizosphere of Poa alpina across a glacier foreland in the Central Alps. Environmental Microbiology 8(9): 1600-1612. http://doi.org/doi:10.1111/j.1462-2920.2006.01051.x

Du J, Singh H, Won K, Yang J-E, Jin F-X, Yi T-H (2015) Sphingobacterium mucilaginosum sp. nov., isolated from rhizosphere soil of a rose. International journal of systematic and evolutionary microbiology 65(Pt_9): 2949-2954. http://doi.org/doi:10.1099/ijs.0.000361

Edgar RC (2013) UPARSE: highly accurate OTU sequences from microbial amplicon reads. Nature methods 10(10): 996-998. http://doi.org/doi:10.1038/nmeth.2604

Edgar RC, Haas BJ, Clemente JC, Quince C, Knight R (2011) UCHIME improves sensitivity and 
speed of chimera detection. Bioinformatics 27(16): 2194-2200. http://doi.org/doi:10.1093/bioinformatics/btr381

Farinotti D, Huss M, Fürst JJ, Landmann J, Machguth H, Maussion F, et al. (2019) A consensus estimate for the ice thickness distribution of all glaciers on Earth. Nature Geoscience 12(3): 168-173. http://doi.org/doi:10.1038/s41561-019-0300-3

Filippidou S, Junier T, Wunderlin T, Lo C-C, Li P-E, Chain PS, et al. (2015) Under-detection of endospore-forming Firmicutes in metagenomic data. Computational and structural biotechnology journal $\quad$ 13: 299-306. http://doi.org/doi:10.1016/j.csbj.2015.04.002

Ganzert L, Lipski A, Hubberten H-W, Wagner D (2011) The impact of different soil parameters on the community structure of dominant bacteria from nine different soils located on Livingston Island, South Shetland Archipelago, Antarctica. FEMS Microbiology Ecology 76(3): 476-491. Retrieved from https://doi.org/10.1111/j.1574-6941.2011.01068.x. http://doi.org/doi:10.1111/j.1574-6941.2011.01068.x

Ghazalpour A, Doss S, Zhang B, Wang S, Plaisier C, Castellanos R, et al. (2006) Integrating genetic and network analysis to characterize genes related to mouse weight. PLoS genetics 2(8): e130. http://doi.org/doi:10.1371/journal.pgen.0020130

Guidi L, Chaffron S, Bittner L, Eveillard D, Larhlimi A, Roux S, et al. (2016) Plankton networks driving carbon export in the oligotrophic ocean. Nature 532(7600): 465-470. http://doi.org/doi:10.1038/nature16942.

Guo Y, Wang N, Li G, Rosas G, Zang J, Ma Y, et al. (2018) Direct and indirect effects of penguin feces on microbiomes in Antarctic ornithogenic soils. Frontiers in microbiology 9: 552. http://doi.org/doi:10.3389/fmicb.2018.00552

Gutiérrez MH, Galand PE, Moffat C, Pantoja S (2015) Melting glacier impacts community structure of $B$ acteria, A rchaea and $F$ ungi in a $C$ hilean $P$ atagonia fjord. Environmental microbiology 17(10): 3882-3897. http://doi.org/doi:10.1111/1462-2920.12872

Hansen AA, Herbert RA, Mikkelsen K, Jensen LL, Kristoffersen T, Tiedje JM, et al. (2007) Viability, diversity and composition of the bacterial community in a high Arctic permafrost soil from Spitsbergen, Northern Norway. Environmental microbiology 9(11): 2870-2884. http://doi.org/doi:10.1111/i.1462-2920.2007.01403.x

Hodson A, Anesio AM, Tranter M, Fountain A, Osborn M, Priscu J, et al. (2008) Glacial ecosystems. Ecological monographs 78(1): 41-67. http://doi.org/doi:10.1890/07-0187.1

Jones RT, Robeson MS, Lauber CL, Hamady M, Knight R, Fierer N (2009) A comprehensive survey of soil acidobacterial diversity using pyrosequencing and clone library analyses. The ISME journal 3(4): 442-453. http://doi.org/doi:10.1038/ismej.2008.127

Kandeler E, Deiglmayr K, Tscherko D, Bru D, Philippot L (2006) Abundance of narG, nirS, nirk, and nosZ genes of denitrifying bacteria during primary successions of a glacier foreland. Applied and environmental microbiology 72(9): 5957-5962. http://doi.org/doi:10.1128/AEM.00439-06

Katz L, Baltz RH (2016) Natural product discovery: past, present, and future. Journal of Industrial Microbiology and Biotechnology 43(2-3): 155-176. http://doi.org/doi:10.1007/s10295-015-1723-5

Kim HM, Jung JY, Yergeau E, Hwang CY, Hinzman L, Nam S, et al. (2014) Bacterial community structure and soil properties of a subarctic tundra soil in Council, Alaska. FEMS microbiology ecology 89(2): 465-475. http://doi.org/doi: 10.1111/1574-6941.12362 
Li Y-Y, Chen X-H, Xie Z-X, Li D-X, Wu P-F, Kong L-F, et al. (2018) Bacterial diversity and nitrogen utilization strategies in the upper layer of the northwestern Pacific Ocean. Frontiers in microbiology 9: 797. http://doi.org/doi: 10.3389/fmicb.2018.00797

Liu Y, Yao T, Jiao N, Kang S, Xu B, Zeng Y, et al. (2009) Bacterial diversity in the snow over Tibetan Plateau Glaciers. Extremophiles 13(3): 411-423. http://doi.org/doi:10.1007/s00792-009-0227-5

Luláková P, Perez-Mon C, Šantrůčková H, Ruethi J, Frey B (2019) High-alpine permafrost and active-layer soil microbiomes differ in their response to elevated temperatures. Frontiers in microbiology 10: 668. http://doi.org/doi: 10.3389/fmicb.2019.00668

Moisander PH, Beinart RA, Hewson I, White AE, Johnson KS, Carlson CA, et al. (2010) Unicellular cyanobacterial distributions broaden the oceanic N2 fixation domain. Science 327(5972): 1512-1514. http://doi.org/doi:10.1126/science.1185468

Moisander PH, Serros T, Paerl RW, Beinart RA, Zehr JP (2014) Gammaproteobacterial diazotrophs and nifH gene expression in surface waters of the South Pacific Ocean. The ISME journal 8(10): 1962-1973. http://doi.org/doi:10.1038/ismej.2014.49

Montoya JP, Holl CM, Zehr JP, Hansen A, Villareal TA, Capone DG (2004) High rates of N 2 fixation by unicellular diazotrophs in the oligotrophic Pacific Ocean. Nature 430(7003): 1027-1031. http://doi.org/doi:10.1038/nature02824

Noël B, Jakobs CL, Van Pelt W, Lhermitte S, Wouters B, Kohler J, et al. (2020) Low elevation of Svalbard glaciers drives high mass loss variability. Nature communications 11(1): 1-8. http://doi.org/doi:10.1038/s41467-020-18356-1

Pendleton SL, Miller GH, Lifton N, Lehman SJ, Southon J, Crump SE, et al. (2019) Rapidly receding Arctic Canada glaciers revealing landscapes continuously ice-covered for more than 40,000 years. Nature communications 10(1): 1-8. http://doi.org/doi:10.1038/s41467-019-08307-w

Quast C, Pruesse E, Yilmaz P, Gerken J, Schweer T, Yarza P, et al. (2012) The SILVA ribosomal RNA gene database project: improved data processing and web-based tools. Nucleic acids research 41(D1): D590-D596. http://doi.org/doi:10.1093/nar/gks1219

Reddy PVV, Rao SSSN, Pratibha MS, Sailaja B, Kavya B, Manorama RR, et al. (2009) Bacterial diversity and bioprospecting for cold-active enzymes from culturable bacteria associated with sediment from a melt water stream of Midtre Lov' enbreen glacier, an Arctic glacier. $\begin{array}{lll}\text { Research in } \quad \text { 160(8): } & \text { 538-546. }\end{array}$ http://doi.org/doi:10.1016/j.resmic.2009.08.008

Rohart F, Gautier B, Singh A, Lê Cao K-A (2017) mixOmics: An R package for 'omics feature selection and multiple data integration. PLoS computational biology 13(11): e1005752. http://doi.org/doi:10.1371/journal.pcbi.1005752

Sajjad W, Ali B, Bahadur A, Ghimire PS, Kang S (2021) Bacterial diversity and communities structural dynamics in soil and meltwater runoff at the frontier of Baishui Glacier No. 1, China. Microbial Ecology 81(2): 370-384. http://doi.org/doi:10.1007/s00248-020-01600-y

Sajjad W, Rafiq M, Din G, Hasan F, Iqbal A, Zada S, et al. (2020) Resurrection of inactive microbes and resistome present in the natural frozen world: Reality or myth? Science of the Total Environment 735: 139275. http://doi.org/doi:10.1016/j.scitotenv.2020.139275

Segata N, Izard J, Waldron L, Gevers D, Miropolsky L, Garrett WS, et al. (2011) Metagenomic 
biomarker discovery and explanation. Genome biology 12(6): 1-18. http://doi.org/doi:10.1186/gb-2011-12-6-r60

Shannon P, Markiel A, Ozier O, Baliga NS, Wang JT, Ramage D, et al. (2003) Cytoscape: a software environment for integrated models of biomolecular interaction networks. Genome research 13(11): 2498-2504. http://doi.org/doi:10.1101/gr.1239303

Shen H, Huang JZ (2008) Sparse principal component analysis via regularized low rank matrix approximation. Journal of multivariate analysis 99(6): 1015-1034. http://doi.org/doi:10.1016/j.jmva.2007.06.007

Shi Y, Xiang X, Shen C, Chu H, Neufeld JD, Walker VK, et al. (2015) Vegetation-associated impacts on arctic tundra bacterial and microeukaryotic communities. Applied and environmental microbiology 81(2): 492-501. http://doi.org/doi:10.1128/AEM.03229-14

Shiozaki T, ljichi M, Kodama T, Takeda S, Furuya K (2014) Heterotrophic bacteria as major nitrogen fixers in the euphotic zone of the Indian Ocean. Global Biogeochemical Cycles 28(10): 1096-1110. http://doi.org/doi:10.1002/2014GB004886.

Steven B, Briggs G, McKay CP, Pollard WH, Greer CW, Whyte LG (2007) Characterization of the microbial diversity in a permafrost sample from the Canadian high Arctic using culture-dependent and culture-independent methods. FEMS microbiology ecology 59(2): 513-523. http://doi.org/doi:10.1111/j.1574-6941.2006.00247.x

Takeuchi N, Kohshima S (2004) A snow algal community on Tyndall Glacier in the Southern Patagonia Icefield, Chile. Arctic, Antarctic, and Alpine Research 36(1): 92-99. http://doi.org/doi:10.1657/1523-0430(2004)036[0092:ASACOT]2.0.CO;2

Undabarrena A, Beltrametti F, Claverías FP, González M, Moore ER, Seeger M, et al. (2016) Exploring the diversity and antimicrobial potential of marine actinobacteria from the comau fjord in Northern Patagonia, Chile. Frontiers in Microbiology 7: 1135. http://doi.org/doi:10.3389/fmicb.2016.01135

Venkatachalam S, Kannan VM, Saritha VN, Loganathachetti DS, Mohan M, Krishnan KP (2021) Bacterial diversity and community structure along the glacier foreland of Midtre Lovénbreen, Svalbard, Arctic. Ecological Indicators 126: 107704. http://doi.org/doi:10.1016/i.ecolind.2021.107704

Vishnivetskaya TA, Petrova MA, Urbance J, Ponder M, Moyer CL, Gilichinsky DA, et al. (2006) Bacterial community in ancient Siberian permafrost as characterized by culture and culture-independent methods. Astrobiology 6(3): 400-414. http://doi.org/doi:10.1089/ast.2006.6.400

Wang N, Guo Y, Li G, Xia Y, Ma M, Zang J, et al. (2019) Geochemical-compositional-functional changes in arctic soil microbiomes post land submergence revealed by metagenomics. Microbes and environments 34: 180-190. http://doi.org/doi:10.1264/jsme2.ME18091

Wang NF, Zhang T, Yang X, Wang S, Yu Y, Dong LL, et al. (2016) Diversity and composition of bacterial community in soils and lake sediments from an arctic lake area. Frontiers in microbiology 7: 1170. http://doi.org/doi:10.3389/fmicb.2016.01170

Wang NF, Zhang T, Zhang F, Wang ET, He JF, Ding H, et al. (2015) Diversity and structure of soil bacterial communities in the Fildes Region (maritime Antarctica) as revealed by 454 pyrosequencing. Frontiers in microbiology 6: 1188. http://doi.org/doi:10.3389/fmicb.2015.01188

Wang Q, Garrity GM, Tiedje JM, Cole JR (2007) Naive Bayesian classifier for rapid assignment of 
rRNA sequences into the new bacterial taxonomy. Applied and environmental microbiology 73(16): 5261-5267. http://doi.org/doi:10.1128/AEM.00062-07

Wilhelm L, Singer GA, Fasching C, Battin TJ, Besemer K (2013) Microbial biodiversity in glacier-fed streams. The ISME journal 7(8): 1651-1660. http://doi.org/doi:10.1038/ismej.2013.44

Yang GL, Hou SG, Le Baoge R, Li ZG, Xu H, Liu YP, et al. (2016) Differences in bacterial diversity and communities between glacial snow and glacial soil on the Chongce Ice Cap, West Kunlun Mountains. Scientific reports 6(1): 1-8. http://doi.org/doi:10.1038/srep36548

Zhang R, Zhang X-Y, Sun X-K, Mu D-S, Du Z-J (2019) Flavobacterium cerinum sp. nov., isolated from Arctic tundra soil. International journal of systematic and evolutionary microbiology 69(12): 3745-3750. http://doi.org/doi:10.1099/ijsem.0.003648

Zhang T, Wang N-F, Zhang Y-Q, Liu H-Y, Yu L-Y (2016) Diversity and distribution of aquatic fungal communities in the $\mathrm{Ny}$-Ålesund region, Svalbard (high arctic). Microbial ecology 71(3): 543-554. http://doi.org/doi:10.1007/s00248-015-0689-1

Zhang X, Ma X, Wang N, Yao T (2009) New subgroup of Bacteroidetes and diverse microorganisms in Tibetan plateau glacial ice provide a biological record of environmental conditions. FEMS microbiology ecology 67(1): 21-29. http://doi.org/doi:10.1111/i.1574-6941.2008.00604.x 